\title{
APPLICATIONS OF PHYLOGENETICS TO ISSUES IN FRESHWATER CRAYFISH BIOLOGY
}

\author{
KEITH A. CRANDALL
}

Department of Integrative Biology, Monte L. Bean Life Science Museum, 675 Widtsoe Building, Brigham Young University, Provo, Utah 84602, USA. E-mail: Keith Crandall@byu.edu

Reçu le 13 juillet 2005

Accepté le 22 novembre 2005

Received July 13, 2005

Accepted November 22, 2005

\begin{abstract}
Freshwater crayfish have served as model organisms for over 125 years in scientific research, from areas such as neurobiology and vision research to conservation biology and evolution. Recently, evolutionary histories in the form of phylogenies have served as a critical foundation for testing hypotheses in such diverse research areas as well. In this article, I review the amazing diversity of freshwater crayfish, especially in a phylogenetic context and explore how these evolutionary histories have informed crayfish biology and can be used powerfully in the future to guide research in a diversity of areas. Throughout the article, I draw on examples from my own laboratory in molecular evolution, vision research, systematics, population genetics, and conservation biology.
\end{abstract}

Key-words: systematics, crayfish, conservation biology, population genetics, molecular evolution.

\section{UTILISATION DE LA PHYLOGÉNÉTIQUE POUR INFÉRER SUR LA BIOLOGIE DE L'ÉCREVISSE}

\section{RÉSUMÉ}

Les écrevisses ont servi d'organisme modèle pour des recherches scientifiques depuis plus de 25 ans, dans des champs disciplinaires variés tels que la neurobiologie ou la vision, jusqu'à la biologie de la conservation et l'évolution. Récemment, les histoires évolutives appréhendées à partir des phylogénies ont servi de base critique pour tester les hypothèses dans ces différents domaines de recherches. Dans cet article, j'ai réexaminé l'incroyable diversité des écrevisses, spécialement dans un contexte phylogénétique et j'ai regardé comment ces histoires évolutives ont pu nous renseigner sur la biologie des écrevisses, et comment elles pourront être utilisées, à l'avenir, pour guider les recherches dans les différents domaines. J'ai illustré cet article par des exemples pris dans mon propre laboratoire dans les domaines de l'évolution, la vision, la systématique, la génétique des populations et la biologie de la conservation. Moléculaire.

Mots-clés : systématique, écrevisse, biologie de la conservation, génétique des populations, évolution moléculaire. 


\section{INTRODUCTION}

Freshwater crayfish are a beautifully diverse group of organisms with over 605 described species of freshwater crayfish distributed throughout North America, Australia, southern South America, Asia, Europe, Madagascar, and New Zealand (summarized at http://crayfish.byu.edu). They come in a variety of sizes, from the members of the dwarf crayfish, Cambarellus (reaching lengths of only $2 \mathrm{~cm}$ as adults), to the world's largest freshwater invertebrate, the endangered Astacopsis gouldii (reaching lengths over $40 \mathrm{~cm}$ and weights over $5 \mathrm{~kg}$ ) (HORWITZ, 1994). These beautiful organisms come in many colors, including red, blue, orange, green, brown, and even pigment-less (white). There are crayfish with spots, stripes, and patterns of various sorts. They are truly a splendor of morphological variation. Indeed, they also have some ecological variation, inhabiting four main habitat types, the fast flowing streams, primary burrowers, pond/lake/slow water species, and the troglobitic (obligate cave) species. It is presumably this ecological diversity coupled with extreme isolation for most species (at least 15 of the 605 species of freshwater crayfish are only known from a single location and most species have very narrow geographic distributions) that has lead to the grand morphological assortment of species. Because of this diversity coupled with a relative ease of collection and their conspicuousness in the ecological community, freshwater crayfish have served as a model organism of study in a variety of sciences. Indeed, over 125 years ago, HUXLEY (1880) produced an introductory text to the study of Zoology based solely on the crayfish.

Phylogenetics is the reconstruction of evolutionary histories using a combination of morphological and/or molecular data. The resulting phylogeny ideally depicts the lines of common ancestry among the group of taxa sampled. The field of systematics strives to assign a classification system that reflects these lines of descent. Thus phylogenies are central to studies of systematics. However, recently phylogenies have been used to study an array of interesting evolutionary hypotheses (PAGEL, 1999). With this paper I strive to introduce the reader to the utility of a phylogenetic approach to study a variety of areas from conservation genetics to molecular evolution through the application to freshwater crayfish model systems. Obviously, this is a fairly limited sampling mostly from my own lab, but I hope it gives the reader a taste for both a phylogenetic approach to hypothesis testing as well as an appreciation for the freshwater crayfish as a model system.

\section{CRAYFISH SYSTEMATICS}

There has been considerable debate concerning the origin(s) of freshwater crayfish as a single or multiple independent events. The two centers of diversity, one in the south east United States and the other in southern Australia (Southern Victoria and Tasmania) coupled with the clear morphological distinctions between the northern and southern hemisphere crayfish in terms of their secondary sexual characteristics have stimulated this debate. Recent work from both the morphological and molecular perspectives seems to support a monophyletic origin with a clear separation between the northern and southern hemisphere crayfish (SCHOLTZ and RICHTER, 1995; CRANDALL et al., 2000a; SCHOLTZ, 2001) (Figure 1). While the work of CRANDALL et al. (2000a) supported the notion of clawed lobsters (Nephropoidea) as being the sister group to the freshwater crayfish (Figure 1), the work by SCHOLTZ and RICHTER (1995) suggested that the Thalassinidea are the sister group to the freshwater crayfish. This debate seems to be ending with the support landing on the crayfish and lobsters as sister taxa (AHYONG and O'MEALLY, 2004; PORTER et al., 2005). Regardless, the freshwater crayfish are a monophyletic group and there is a clear division between the northern and southern hemisphere superfamilies (Astacoidea and Parastacoidea), consistent with a Pangaean origin at least in the Triassic (185-225 million years ago). Indeed this phylogenetic evidence is supported by fossil evidence of crayfish and burrows from Colorado and Utah dating to the Permian and Early Triassic (265 million years ago) (HASIOTIS and BOWN, 1997). 


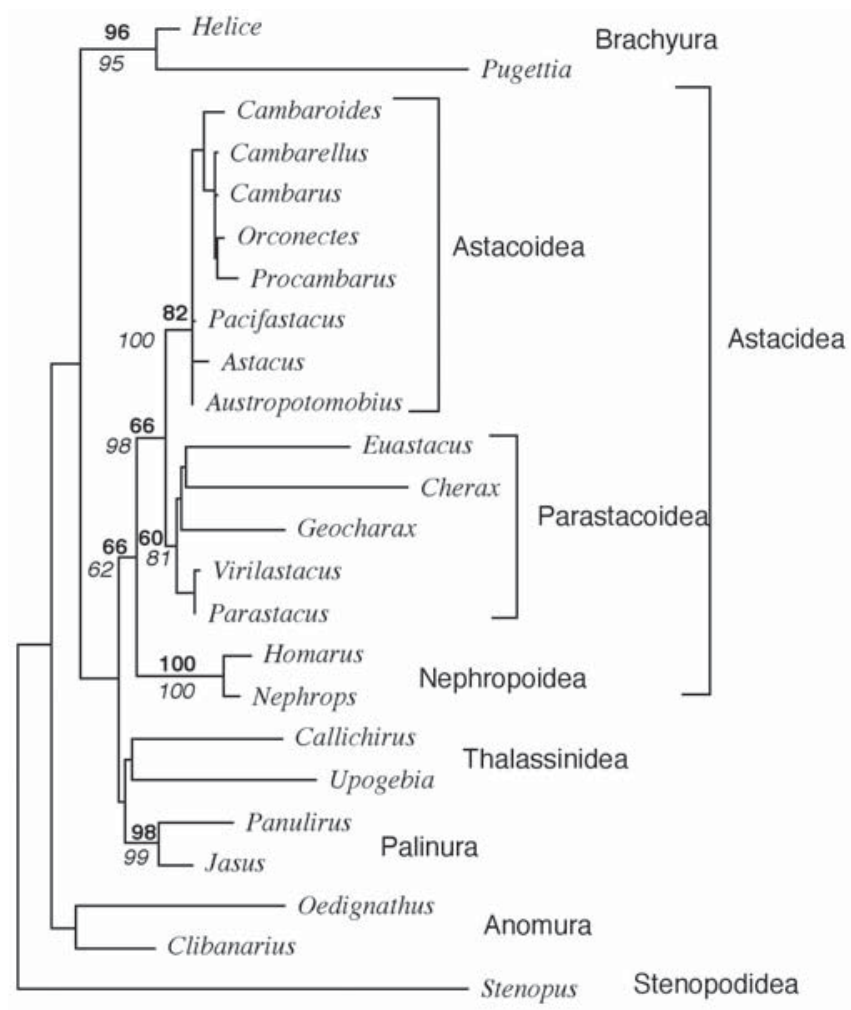

0.01 substitutions per site

\section{Figure 1}

A maximum-likelihood estimate of phylogenetic relationships among freshwater crayfish (Astacoidea and Parastacoidea) and other Crustacea estimated from nucleotide sequence data from the $18 \mathrm{~S}$ ribosomal gene. Nodal support is indicated with bootstrap values from both maximum parsimony searches (bold) and maximum-likelihood searches (italics) of 1,000 bootstrap replications each. From (CRANDALL et al., 2000).

\section{Figure 1}

Relations phylogénétiques, obtenues à partir du maximum de vraisemblance entre les écrevisses (Astacoidea et Parastacoidea) et les autres crustacés à partir de séquences nucléotidiques du gène ribosomique 18S. Les nœuds indiquent les valeurs de bootstrap (pour 1000 réplications) pour une recherche en parcimonie (en gras) et une recherche en maximum de vraisemblance (italique). Dans (CRANDALL et al., 2000).

The freshwater crayfish are divided into three families (Astacidae, Cambaridae, and Parastacidae) with 3,12 , and 16 genera in each, respectively. There has yet to be a single study that evaluates all the genera from all three families from either a morphological or molecular perspective. Preliminary indications are that the Parastacidae form a monophyletic group (CRANDALL et al., 2000a; CRANDALL et al., 2000b). However, the Cambaridae and Astacidae appear to be nonmonophyletic assemblages due to the clustering of the genus Cambaroides (from Asia, currently classified in the family Cambaridae) with the genus Pacifastacus (from the north-west United States and south-west Canada, currently classified in the family Astacidae) (Figure 2). While this 


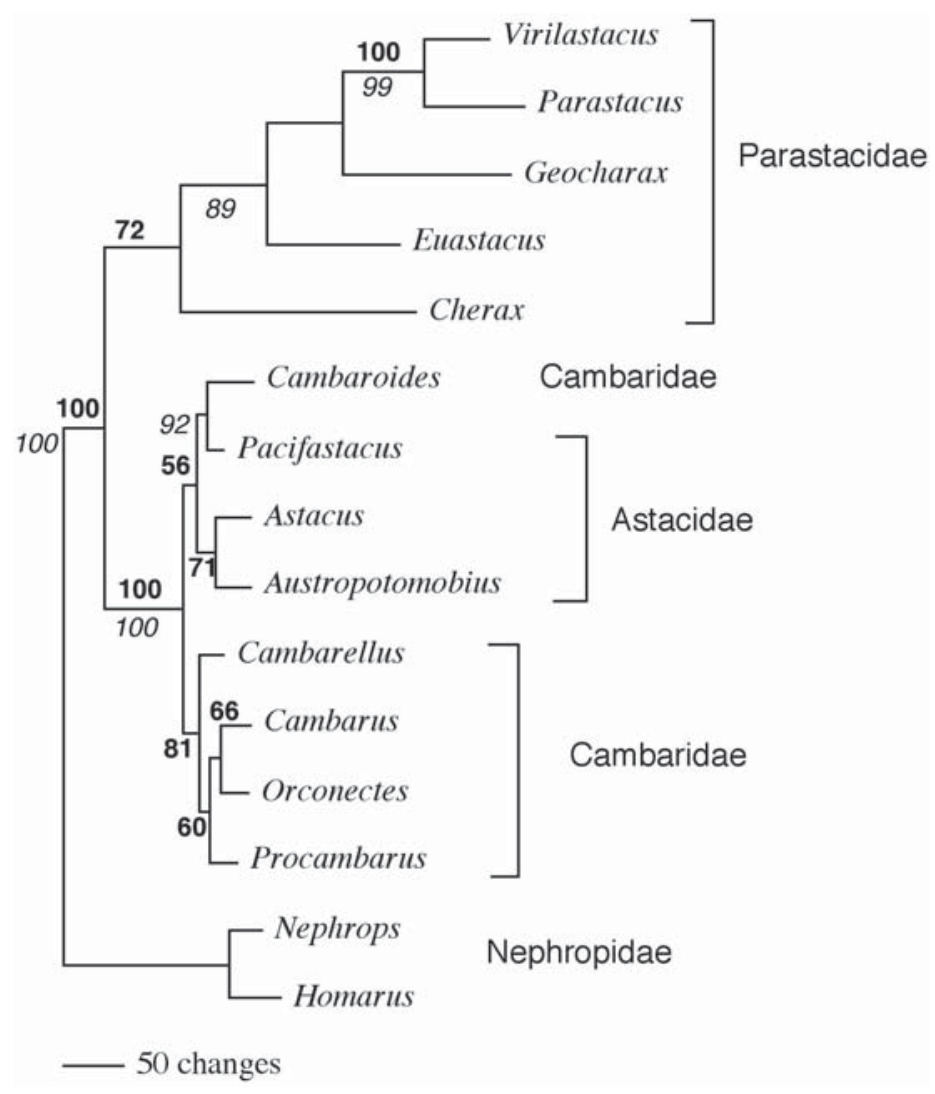

Figure 2

A maximum-likelihood phylogeny of the freshwater crayfish families with clawed lobsters serving as an outgroup. This tree was estimated from nucleotide sequence data from the $28 \mathrm{~S}, 18 \mathrm{~S}$, and $16 \mathrm{~S}$ ribosomal genes representing over 3,400 characters for phylogenetic inference. Bootstrap values indicate nodal support for maximum parsimony (bold) and maximum likelihood (italics) bootstrap searchers based on 1,000 bootstrap replications.

Figure 2

Relations phylogénétiques des familles d'écrevisses, obtenues à partir du maximum de vraisemblance avec comme groupe externe les homards. Cet arbre est estimé à partir de séquences nucléotidiques, obtenues pour les gènes 28S, $18 \mathrm{~S}$ et $16 \mathrm{~S}$, représentant plus 3400 caractères utilisés pour des inférences phylogénétiques. Les nœuds indiquent les valeurs de bootstrap (pour 1000 réplications) pour une recherche en parcimonie (en gras) et une recherche en maximum de vraisemblance (italique).

preliminary work provides an excellent phylogenetic framework for comparative biology, much work remains in establishing robust phylogenetic relationships both within the freshwater crayfish families and among the families relative to various potential sister taxa. Morphological data has been notoriously difficult to collect for phylogenetic information because of the large number of species relative to paucity of discrete characters. Allozyme data also proved to be relatively uninformative with freshwater crayfish showing extremely low levels of variation. However, nucleotide sequence data, mtDNA restriction site data, and recently microsatellite data have proven to be very useful for both population genetics and systematics of crayfish. FETZNER and CRANDALL (2001) have recently reviewed 
the genetic literature on crayfish from chromosomal information to primers for nucleotide sequencing and microsatellite work. The resulting phylogenetic hypotheses allow us to assess current classification systems and use the freshwater crayfish as a model system in a diversity of studies. We recently compiled a $16 \mathrm{SrDNA}$ estimated phylogeny from a broad spectrum of freshwater crayfish across 26 of the extant genera and the resulting phylogeny again showed a clear Northern and Southern Hemisphere split (Figure 3). The phylogeny also suggested that most of the Southern Hemisphere genera are wellsupported monophyletic groups, yet the Northern Hemisphere genera show substantial mixing of taxa across the phylogeny. The branch lengths associated with the Southern Hemisphere crayfishes are also much longer than their Northern Hemisphere counterparts suggesting the generic level partitions in the Parastacidae are much older than in the Cambaridae and Astacidae.

\section{MOLECULAR EVOLUTION}

Freshwater crayfish have served as a model system in vision research for some time. Indeed, George Wald, 1967 Nobel Laureate in Medicine for discoveries concerning the primary physiological and chemical visual processes in the eye, used the crayfish in his elucidation of the role of vitamin A in vision (WALD, 1967; WALD, 1968). While clearly at a different scale, my lab has continued to use the freshwater crayfish as a model system to study the molecular evolution of visual pigment genes in response to their photic environment, but using a phylogenetic context to test hypotheses. We have sequenced the visual pigment gene rhodopsin from troglobitic (obligate cave dwellers with no pigmentation and no eyes!) crayfish species and their nearest surface dwelling species (Figure 4). Crayfish represent a wonderful system to study the impact of the lightfree cave environment on the molecular evolution of the opsin whose function is to absorb light because distinct lineages of crayfish have independently evolved cave adaptations (HOBBS and BARR, 1972). We sequenced the opsin gene from three species pairs, showing that there were equal rates of both synonymous (nucleotide substitutions that do not change the coded amino acid) and nonsynonymous (nucleotide substitutions that do change the amino acid) substitutions between the cave and surface lineages (Figure 5; CRANDALL and HILLIS, 1997). Furthermore, there were no changes in the placement of the changes with respect to the functional domains of the protein, e.g., the chromophore binding pocket showed no changes in the cave or surface species do the functional constraints on this region. We therefore concluded that the gene was still functional, yet could not be performing the known function of light absorption due to the lack of light. The opsin must, therefore, be performing a here-to-fore unknown function. Our lab continues work to elucidate the potential function of this gene as well as identifying genes and mutations involved in the eye development and degeneration process. We also have an interest in understanding the impact of different ecological conditions on the functionality of the opsin gene (CRANDALL and CRONIN, 1997) and continue to work on similar projects (PORTER and CRANDALL, 2003).

\section{POPULATION GENETICS}

One of the fundamental questions in evolutionary biology is how gene frequencies change as a result of population subdivision and isolation. My lab has been extensively involved in developing bioinformatic tools for identifying population subdivision and historical events in the evolutionary history of a population (TEMPLETON et al., 1992; CLEMENT et al., 2000; POSADA et al., 2000). We have also utilized the crayfish model system as a way of testing some of these methods. For example, the principle behind our method is to compare genetic distances with geographic distances for evidence of past historic events such as genetic fragmentation events or genetic structure such as isolation by distance. Because crayfish inhabit a linear aquatic habitat, geographic 


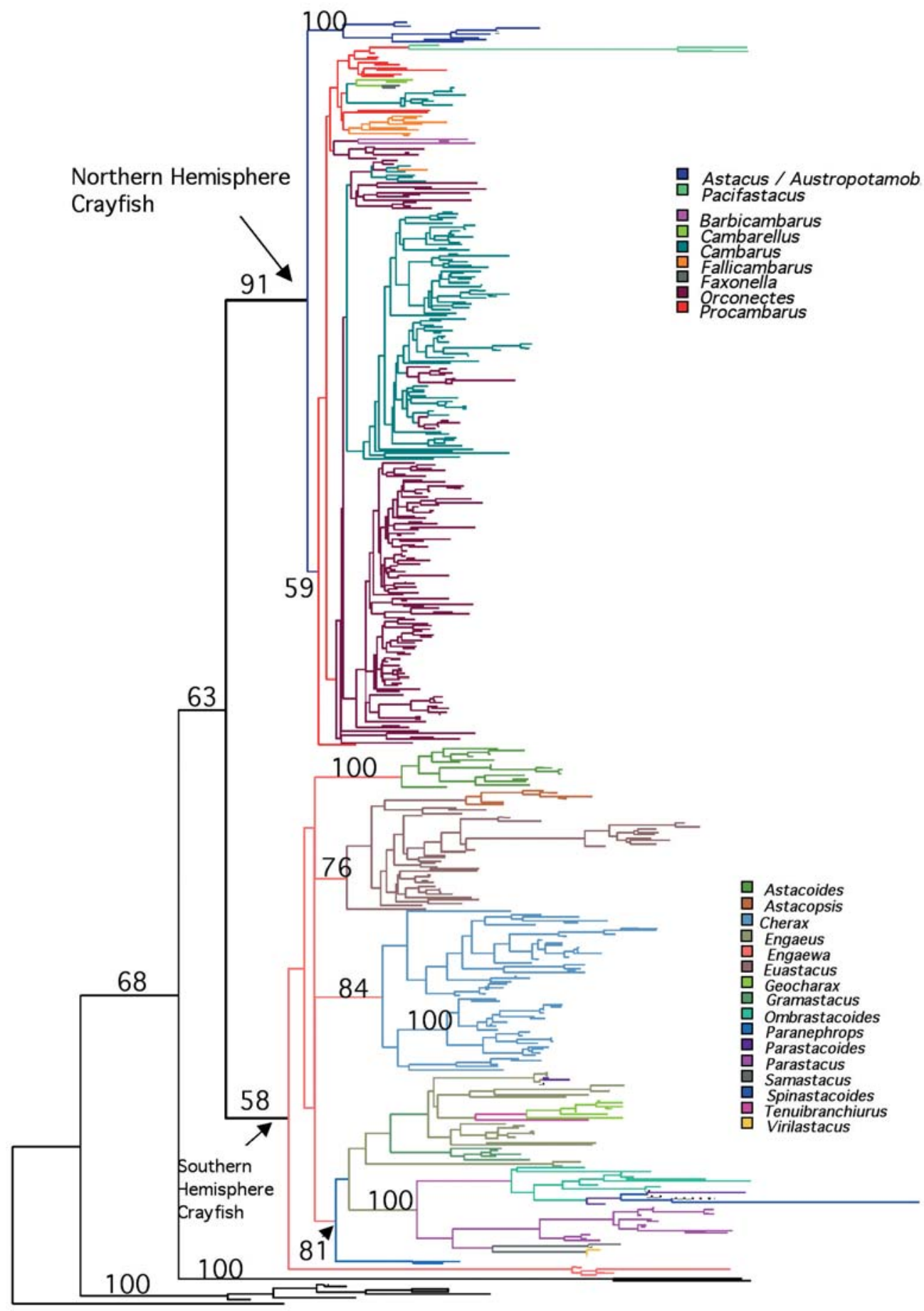

Figure 3

ML tree of 455 16SrDNA sequences from freshwater crayfish representing 227 species, over one third of the currently recognized crayfish species (SINCLAIR et al., 2004).

Figure 3

Arbre obtenu en maximum de vraisemblance à partir de 455 séquences de 16SADNr représentant 227 espèces d'écrevisses, soit plus du tiers des espèces reconnues pour ce groupe (SINCLAIR et al., 2004). 


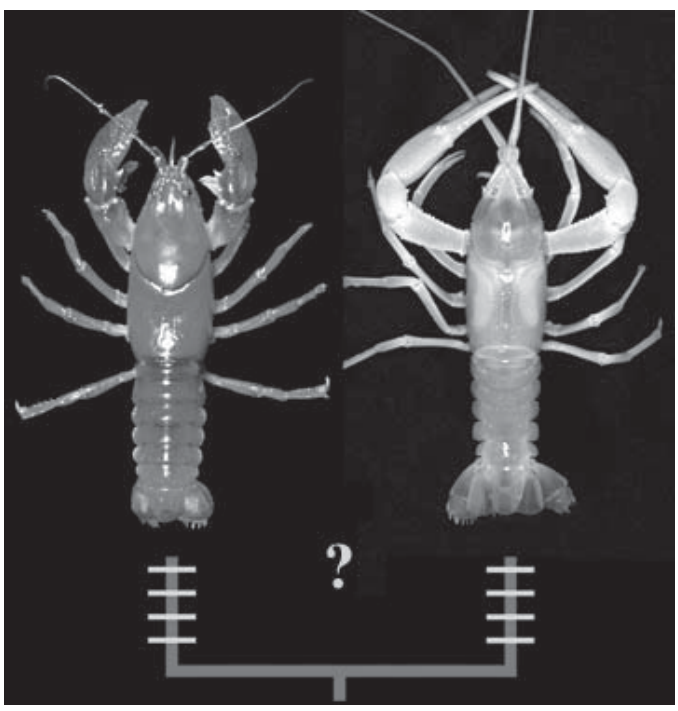

Figure 4

Opsin genes were sequenced from both surface (Cambarus asperimanus) and cave (Cambarus setosus) species to compare the relative molecular changes in the visual pigment gene when it is housed in an organism that has not experienced light for millions of years.

Figure 4

Le gène de l'opsine a été séquencé à partir d'écrevisses de surface (Cambarus asperimanus) et d'écrevisses cavernicoles (Cambarus setosus) pour comparer les changements moléculaires dans ce gène codant pour les pigments oculaires, l'organisme cavernicole n'ayant pas reçu de lumière depuis des millions d'années.

distances can be considered differently relative to organisms with two-dimensional dispersal capabilities. Therefore, FETZNER and CRANDALL (2003) investigated the impact of the one-dimensional habitat versus the two-dimensional habitat on the population genetic inferences resulting from the nested clade analysis approach. We found that the inferences can be severely affected by the choice of geographic distances and that for stream organisms and other organisms with linear habitats the appropriate inferences are made using these linear distances. We then have applied these methods to investigate the population structure of various crayfish species identifying in many cases significant population subdivision suggesting cryptic species (CRANDALL and FITZPATRICK, 1996; FETZNER and CRANDALL, 1999; 2003; BUHAY and CRANDALL, 2005). In association with the application of these approaches to population genetic questions, we have developed a set of molecular tools in the form of AFLPs, microsatellites, and PCR primers for various gene regions that can be used to investigate population genetic questions as well as systematic questions. We have recently summarized our current database of genetic variation in crayfish and associated genetic methodological resources (FETZNER and CRANDALL, 2001).

\section{CONSERVATION BIOLOGY}

One of my lab's principle interests in understanding historical population structure is in the context of conservation biology. We have used phylogenetic information to infer population structure coupled with ecological information to identify cryptic species and/or 


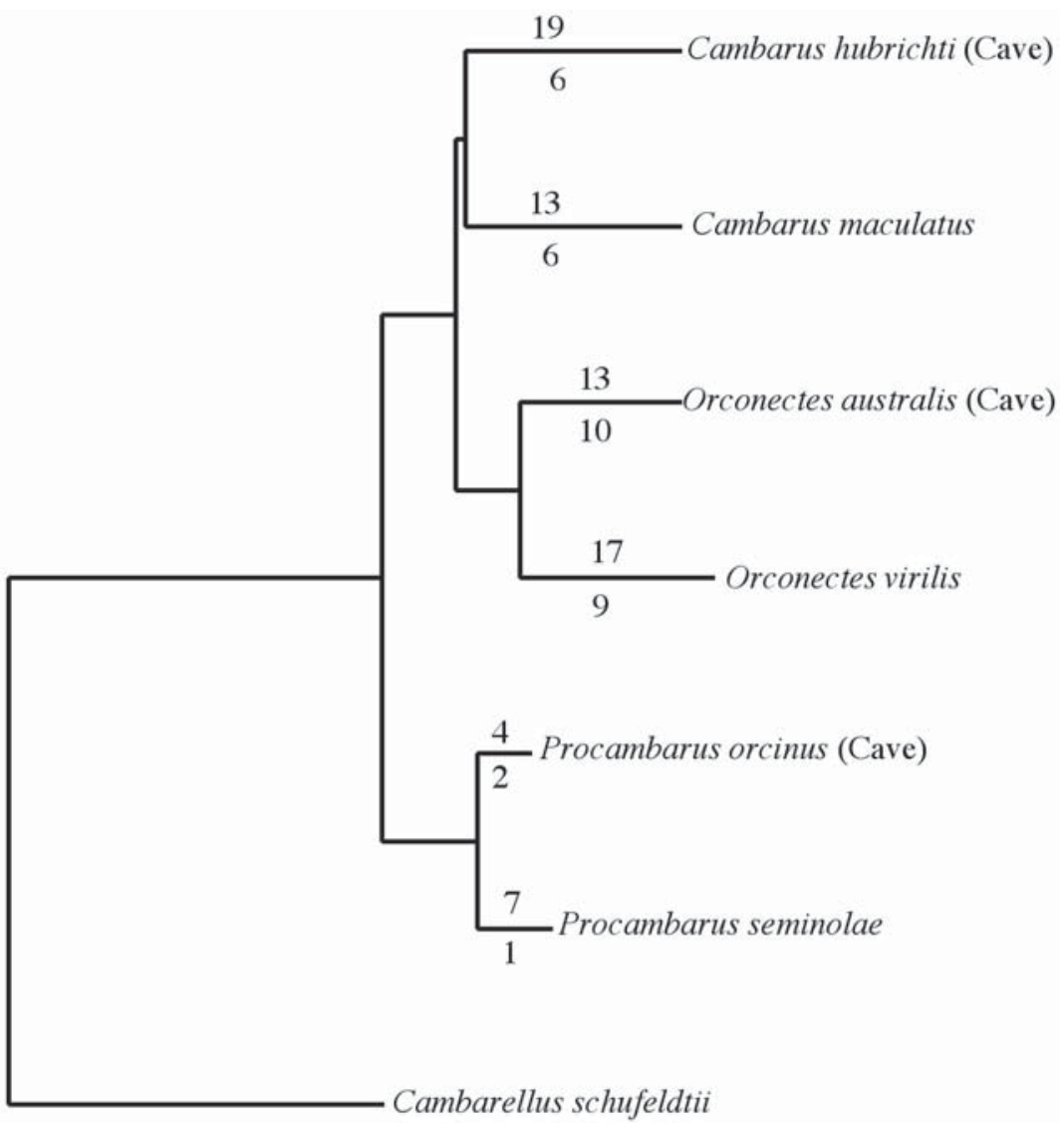

Figure 5

Maximum-likelihood reconstructed evolutionary changes in synonymous (above the branches) and nonsynonymous (below the branches) substitutions in the cave and surface lineages of freshwater crayfish.

\section{Figure 5}

Changements évolutionnaires construits en maximum de vraisemblance à partir de substitutions synonymes (au-dessus des branches) et non synonymes (en dessus des branches) entre les écrevisses cavernicoles et les différentes lignées d'écrevisses de surface.

evolutionarily significant units within a single morphologically defined species (CRANDALL et al., 2000). We have used this conceptual framework and applied it to the plight of the freshwater crayfish. In United States and Canada, over half of the freshwater crayfish are considered endangered to some degree (TAYLOR et al., 1996). At least 15 species are known from only a single locality, and most have a very limited geographic range. There are a few widespread species that have been introduced to non-native habitats (e.g., Procambarus clarkii, Orconectes virilis, Orconectes rusticus) and have had significant detrimental impacts on the native fauna (OLSEN et al., 1991; GAMRADT et al., 1997) and associated habitats (RABENI, 1992; USIO, 2000). These species give crayfish a bad name in conservation circles. Consequently, the conservation status of the majority of the crayfish species, which are endangered, are typically ignored by the conservation community. We have taken the tools developed for population genetic and phylogenetic assessment and applied them to conservation assessment of freshwater crayfish (e.g., 
CRANDALL, 1998; BUHAY and CRANDALL, 2005). We have also used these crayfish as a model stream organism to assess different stream systems for conservation priorities (e.g., CRANDALL, 1998; WHITING et al., 2000), hoping that the phylogenetic diversity measured in the freshwater crayfish is somehow representative of the diversity in other stream organisms as well (e.g., PÉREZ-LOSADA et al., 2002). Sometimes, the genetic data provide surprising results in terms of conservation work on crayfish. For example, our recent conservation genetic research on some cave species in the genus Orconectes suggested that these cave species have much larger effective population sizes than previously thought and that these population sizes seem to me more or less stable over long evolutionary timeframes (BUHAY and CRANDALL, 2005). Much work remains to be done in terms of a thorough conservation assessment of all crayfish species followed by obtaining appropriate protection for those species most imperiled. Our lab is actively working to complete such an assessment.

\section{CONCLUSIONS}

I have attempted to highlight the ways in which my own lab has used the freshwater crayfish as a model organism in a variety of areas to ask a variety of questions using a phylogenetic approach. This is clearly the tip of the iceberg in terms of interesting and valuable science with the crayfish as the model system or with phylogenetic tools. I hope this article motivates readers to delve deeper into the wonderful world of crayfish and/or the fascinating world of phylogenetics (FELSENSTEIN, 2003).

\section{ACKNOWLEDGEMENTS}

I thank Francesca Gherardi for inviting this contribution and hosting such a wonderful meeting in Florence. Most of the work presented in this paper is the result of wonderful and talented students and postdocs from my lab. I thank them for their continued stimulation and excitement for all things phylogenetic.

\section{REFERENCES}

AHYONG S.T., O'MEALLY D., 2004. Phylogeny of the Decapoda Reptantia: resolution using three molecular loci and morphology. The Raffles Bulletin of Zoology, 52, 673-693.

BUHAY J.E., CRANDALL K.A., 2005. Subterranean phylogeography of freshwater crayfishes shows extensive gene flow and surprisingly large population sizes. Molecular Ecology, 14, 4259-4273.

CLEMENT M., POSADA D., CRANDALL K.A., 2000. TCS: a computer program to estimate gene genealogies. Molecular Ecology, 9, 1657-1659.

CRANDALL K.A., 1998. Conservation phylogenetics of Ozark crayfish: Assigning priorities for aquatic habitat protection. Biological Conservation, 84, 107-117.

CRANDALL K.A., BININDA-EMONDS O.R.P., MACE G.M., WAYNE R.K., 2000. Considering evolutionary processes in conservation biology. Trends in Ecology and Evolution, 15, 290-295.

CRANDALL K.A., CRONIN T.W., 1997. The molecular evolution of visual pigments in freshwater crayfish (Decapoda: Cambaridae). Journal of Molecular Evolution, 45, 524-534.

CRANDALL K.A., FETZNER J.W., JR., JARA C.G., BUCKUP L., 2000b. On the phylogenetic positioning of the South American freshwater crayfish genera (Decapoda: Parastacidae). Journal of Crustacean Biology, 20, 530-540. 
CRANDALL K.A., FITZPATRICK J.F., Jr., 1996. Crayfish molecular systematics: Using a combination of procedures to estimate phylogeny. Systematic Biology, 45, 1-26.

CRANDALL K.A., HARRIS D.J., FETZNER J.W., 2000a. The monophyletic origin of freshwater crayfish estimated from nuclear and mitochondrial DNA sequences. Proceedings of the Royal Society of London, Series B, 267, 1679-1686.

CRANDALL K.A., HILLIS D.M., 1997. Rhodopsin evolution in the dark. Nature, 387, 667668.

FELSENSTEIN J., 2003. Inferring Phylogenies. Sinauer Associates, Sunderland, MA.

FETZNER J.W., JR., CRANDALL K.A., 1999. Genetic variability within and among populations of the Golden Crayfish (Orconectes luteus): A comparison using amplified fragment length polymorphisms (AFLPs) and mitochondrial $16 \mathrm{~S}$ gene sequences. Freshwater Crayfish, 12, 396-412.

FETZNER J.W., JR., CRANDALL K.A., 2001. Genetic variation. In: HOLDICH, D.M. (Ed.), Biology of Freshwater Crayfish, 291-326. Blackwell Science, Oxford.

FETZNER J.W., JR., CRANDALL K.A., 2003. Linear habitats and the nested clade analysis: An empirical evaluation of geographic vs. river distances using an Ozark crayfish (Decapoda: Cambaridae). Evolution, 57, 2101-2118.

GAMRADT S.C., KATS L.B., ANZALONE C. B., 1997. Aggression by non-native crayfish deters breeding in California newts. Conservation Biology, 11, 793-796.

HASIOTIS S.T., BOWN T.M., 1997. A short note about crayfish burrows from the PaleoceneEocene, Clarion Formation southwestern Utah, USA. Freshwater Crayfish, 11, 121129.

HOBBS H.H., JR., BARR T.C., Jr., 1972. Origins and affinities of the troglobitic crayfish of North America (Decapoda: Astacidae). II. Genus Orconectes. Smithsonian Contributions to Zoology, 105, 1-84.

HORWITZ P., 1994. Distribution and conservation status of the Tasmanian giant freshwater lobster Astacopsis gouldi (Decapoda: Parastacidae). Biological Conservation, 69, 199-206.

HUXLEY T.H., 1880. The Crayfish: An Introduction to the Study of Zoology. D. Appleton, New York.

OLSEN T.M., LODGE D.M., CAPELL, G.M., HOULIHAN R.J., 1991. Mechanisms of impact of an introduced crayfish (Orconectes rusticus) on littoral congeners, snails, and macrophytes. Canadian Journal of Fisheries and Aquatic Sciences, 48, 18531861.

PAGEL M., 1999. Inferring the historical patterns of biological evolution. Nature, 40, 877884.

PÉREZ-LOSADA M., JARA C.G., BOND-BUCKUP G., CRANDALL K.A., 2002. Conservation phylogenetics of Chilean freshwater crabs Aegla (Anomura, Aeglidae): Assigning priorities for aquatic habitat protection. Biological Conservation, 105, 345-353.

PORTER M.L., CRANDALL K.A., 2003. Lost along the way: The significance of evolution in reverse. Trends in Ecology and Evolution, 18, 541-547.

PORTER M.L., PEREZ-LOSADA M., CRANDALL K.A., 2005. Model based multi-locus estimation of Decapod phylogeny and divergence times. Molecular Phylogenetics and Evolution, 37, 355-369.

POSADA D., CRANDALL K.A., TEMPLETON A.R., 2000. GeoDis: A program for the cladistic nested analysis of the geographical distribution of genetic haplotypes. Molecular Ecology, 9, 487-488. 
RABENI C.F., 1992. Trophic linkage between stream centrarchids and their crayfish prey. Canadian Journal of Fisheries and Aquatic Sciences, 49, 1714-1721.

SCHOLTZ G., 2001. Phylogeny and evolution. In: HOLDICH D.M. (Ed.), Biology of Freshwater Crayfish, 30-52. Blackwell Science, Oxford.

SCHOLTZ G., RICHTER S., 1995. Phylogenetic systematics of the reptantian Decapoda (Crustacea, Malacostraca). Zoological Journal of the Linnean Society, 113, 289328.

SINCLAIR E.A., FETZNER J.W., JR., BUHAY J., CRANDALL K.A., 2004. Proposal to complete a phylogenetic taxonomy and systematic revision for freshwater crayfish (Astacida). Freshwater Crayfish, 14, 1-9.

TAYLOR C.A., WARREN M.L., JR., FITZPATRICK J.F., JR., HOBBS III H.H., JEZERINAC R.F., PFLIEGER W.L., ROBISON H.W., 1996. Conservation status of crayfish of the United States and Canada. Fisheries, 21, 25-38.

TEMPLETON A.R., CRANDALL K.A., SING C.F., 1992. A cladistic analysis of phenotypic associations with haplotypes inferred from restriction endonuclease mapping and DNA sequence data. III. Cladogram estimation. Genetics, 132, 619-633.

USIO N., 2000. Effects of crayfish on leaf processing and invertebrate colonisation of leaves in a headwater stream: decoupling of a trophic cascade. Oecologia, 124, 608-614.

WALD G., 1967. Visual pigments of crayfish. Nature, 215, 1131-1133.

WALD G., 1968. The molecular basis of visual excitation. Nature, 219, 800-807.

WHITING A.S., LAWLER S.H., HORWITZ P., CRANDALL K.A., 2000. Biogeographic regionalisation of Australia: Assigning conservation priorities based on endemic freshwater crayfish phylogenetics. Animal Conservation, 3, 155-163. 
